\title{
Campuran Herbisida Glifosat dan Pupuk Urea Pada Beberapa Taraf Dosis Pada Untuk Mengendalikan Gulma Alang-alang (Imperata cylindrica L.)
}

\author{
The Mixture of Glyphosate Herbicide and Urea Fertilizers at Several Doses \\ Against Imperata Weeds (Imperata cylindrical L.)
}

\author{
Eva Rianti, Bhaidawi dan Abdullah \\ Jurusan Agroteknologi Fakultas Pertanian Universitas Malikussaleh \\ Muara Batu Lhokseumawe
}

\begin{abstract}
Abstrak
Gulma alang-alang tergolong gulma yang sangat sulit untuk dikendalikan. Hal ini karena alang-alang dapat beregenerasi dengan cepat melalui stolon dan bijinya. Pengendalian gulma pada prinsipnya merupakan usaha meningkatkan daya saing tanaman pokok dan melemahkan daya saing gulma. Penggunaan herbisida glifosat dapat dicampur dengan bahan lainnya, salah satunya yaitu pupuk urea. Penelitian ini bertujuan untuk mengetahui apakah campuran herbisida glifosat dan pupuk urea pada beberapa taraf dosis dapat menekan pertumbuhan gulma. Penelitian ini menggunakan Rancangan Acak Kelompok (RAK) pola faktorial, dengan dua faktor yang diteliti yaitu faktor dosis glifosat (G) ; $\mathrm{G}_{0}$ (kontrol), $\mathrm{G}_{1}$ (glifosat $100 \mathrm{ml}$ liter), dan $\mathrm{G}_{2}$ (glifosat $200 \mathrm{ml}$ liter). Faktor pupuk urea (P); $\mathrm{P}_{0}$ (kontrol), $\mathrm{P}_{1}$ (urea 400 gram), dan $\mathrm{P}_{2}$ (urea 600 gram). Hasil penelitian menunjukkan bahwa campuran herbisida glifosat dan pupuk urea dapat menekan pertumbuhan dan perkembangan gulma alang-alang. Perlakuan terbaik dijumpai pada campuran herbisida glifosat dengan dosis $200 \mathrm{ml}$ dan pupuk urea dengan dosis 600 gram, sedangkan perlakuan terendah dijumpai pada kontrol.
\end{abstract}

Kata kunci: Gulma, alang-alang, herbisida, pupuk urea

\begin{abstract}
Imperata weeds are very difficult to control. It is because the weeds have ability to regenerate rapidly through the stolon and seed. Weed control in principle is an effort to increase the competitiveness of basic crops and weaken the competitiveness of weeds. The use of glyphosate herbicide can be mixed with other ingredients; one of them is urea fertilizer. This study aims to reveal whether the mixture of glyphosate herbicide and urea fertilizer at several doses can suppress weed growth. This study used Randomized Block Design factorial pattern, with two factors: (1) dose factor of glyphosate (G); G0 (control), G1 (glyphosate $100 \mathrm{ml}$ liter), and G2 (200 ml liters of glyphosate). (2) urea fertilizer (P); P0 (control), P1 (urea 400 gram), and P2 (urea 600 gram). The results showed that the mixture of glyphosate herbicide and urea fertilizer can suppress the growth and development of imperata weeds. The best treatment was found in a mixture of $200 \mathrm{ml}$ of glyphosate herbicide and urea fertilizer at a dose of 600 grams, while the lowest treatment was found in the control.
\end{abstract}

Keywords: imperata weeds, herbicide, urea fertilizer

\section{Pendahuluan}

Gulma didefinisikan sebagai kelompok jenis tumbuhan yang hidupnya atau tumbuhnya tidak dikehendaki oleh manusia karena dianggap mengganggu dan bisa merugikan hasil tanaman yang dibudidayakan bersifat kuantitatif (kerugian dalam bentuk jumlah atau dapat diwujudkan dengan angka) dan bersifat kualitatif (kerugian dalam bentuk kualitas hasil pertanian yang tidak dapat diwujudkan dengan angka). Gulma juga dapat diartikan sebagai tumbuhan pengganggu tanaman budidaya. Gulma juga dapat didefinisikan sebagai tumbuhan yang kehadirannya tidak diinginkan pada lahan pertanian karena menurunkan hasil yang bisa 
dicapai oleh tanaman produksi. Batasan gulma bersifat teknis dan plastis. Teknis, karena berkait dengan proses produksi suatu tanaman pertanian. Keberadaan gulma menurunkan hasil karena mengganggu pertumbuhan tanaman produksi melalui kompetisi. Plastis, karena batasan ini tidak mengikat suatu spesies tumbuhan. Pada tingkat tertentu, tanaman berguna dapat menjadi gulma. Sebaliknya, tumbuhan yang biasanya dianggap gulma dapat pula dianggap tidak mengganggu (Martin, 2006).

Alang-alang (Imperata cylindrica L.) merupakan tumbuhan pioner pada lahan terbuka akibat penebangan, kebakaran hutan, cara pengelolaan tanah yang kurang baik seperti yang terjadi di daerah-daerah transmigrasi. Alangalang merupakan gulma yang mempunyai kemampuan tumbuh sangat mengagumkan. Alang-alang dapat berkembang biak melalui biji atau rhizom (akar rimpang). Sifatnya yang mudah terbakar, mengakibatkan terjadinya titiktitik api yang dapat membakar kawasan hutan disekitarnya dan menyebabkan terjadinya pencemaran lingkungan/ udara (PPPTP, 2007).

Pengendalian gulma (weed control) dapat didefinisikan sebagai proses untuk membatasi investasi gulma sedemikian rupa sehingga tanaman dapat dibudidayakan secara produktif dan efisien. Dalam pengendalian gulma tidak ada keharusan untuk membunuh gulma, melainkan cukup menekan pertumbuhan atau mengurangi populasinya sampai pada tingkat dimana penurunan produksi yang terjadi tidak berpengaruh terhadap hasil yang diperoleh atau keuntungan yang diperoleh dari penekanan gulma sedapat mungkin seimbang dengan usaha ataupun biaya yang dikeluarkan. Dengan kata lain pengendalian bertujuan hanya menekan populasi gulma sampai tingkat populasi yang tidak merugikan secara ekonomis atau tidak melampaui ambang ekonomi (economic threshold), sehingga sama sekali tidak bertujuan menekan populasi gulma sampai nol.

Gulma alang-alang tergolong gulma yang sangat sulit untuk dikendalikan. Hal ini karena alang-alang dapat beregenerasi dengan cepat melalui stolon dan bijinya. Alang-alang pun memiliki ketahanan hidup yang tinggi pada kondisi lingkungan yang beragam. Kendati demikian, pertumbuhan alang-alang dapat dilakukan pengendalian dengan menggunakan herbisida (secara kimiawi). Karena dapat menimbulkan dampak yang serius bagi lahan budidaya, pengendalian gulma dengan menggunakan metode kimiawi sebaiknya dipilih sebagai opsi terakhir bila cara-cara lain tidak cukup efektif. Bahan kimia yang digunakan berupa herbisida. Dalam penerapannya harus mematuhi petunjuk pemakaian dari produk herbisida tersebut agar tidak menimbulkan dampak negatif yang serius (Sukman, 2002).

Pengendalian gulma pada prinsipnya merupakan usaha meningkatkan daya saing tanaman pokok dan melemahkan daya saing gulma. Keunggulan tanaman pokok harus menjadi sedemikian rupa sehingga gulma tidak mampu mengembangkan pertumbuhannya secara berdampingan atau pada waktu bersamaan dengan tanaman pokok. Pelaksanaan pengendalian gulma hendaknya didasari dengan pengetahuan yang cukup mengenai gulma yang bersangkutan. Apakah gulma tersebut bersiklus hidup annual, biennial ataupun perennial, bagaimana berkembang biaknya, bagaimana sistem penyebarannya, bagaimana dapat beradaptasi dengan lingkungan dan dimana saja distribusinya, bagaimana bereaksi terhadap perubahan lingkungan dan bagaimana tanggapannya terhadap perlakuan-perlakuan tertentu termasuk penggunaan zat-zat kimia berupa herbisida (Adimihardja, 2005).

Penggunaan herbisida perlu adanya pengetahuan yang benar mengenai penggunaan herbisida yang tepat. Pelaksanaan pengendalian gulma dengan herbisida jika terjadi kesalahan aplikasi atau dosisnya terlampau tinggi dan tidak selektif akan mengakibatkan keracunan atau dapat mengakibatkan kematian tanaman. Waktu aplikasi herbisida bervariasi sesuai dengan cara kerjanya seperti pra tanam, pra tumbuh, atau pasca tumbuh. Sedangkan sebelum melakukan penyemprotan gulma dengan herbisida perlu dilakukan kalibrasi alat agar herbisida yang disemprotkan dapat diterima merata pada seluruh luasan lahannya.

Glifosat merupakan herbisida sistemik

yang dapat bereaksi lebih lambat dari pada herbisida jenis organik. Menguningnya daun merupakan gejala visual yang pertama terhadap toksisitas herbisida. Satu minggu setelah penyemprotan, biasanya timbul efek warna coklat tua hingga satu bulan kemudian, tergantung pada ketahanan gulma. Semua formulasi glifosat dievaluasi dalam penelitian menghasilkan gejala awal yang serupa pada tanaman. (James dan Rahman, 2005). Penggunaan salah satu jenis herbisida secara terus menerus dapat menyebabkan gulma 
menjadi resisten. Untuk menghindari hal tersebut, maka diusahakan mencampurkan dua jenis herbisida dalam mengendalikan gulma. Berbagai bahan kimia dipandang mempunyai prospek yang baik untuk mengendalikan gulma, akan tetapi efektif tidaknya suatu herbisida yang digunakan bergantung pada jenis dan dosis herbisida yang diberikan serta besar kecilnya pengaruh lingkungan. Penggunaan herbisida glifosat dapat dicampur dengan bahan lainnya, salah satunya yaitu pupuk urea. Penentuan dosis yang tepat dalam mencampur keduanya tentu akan berpengaruh terhadap pertumbuhan gulma alang-alang.

\section{Bahan dan Metode}

Penelitian dilaksanakan di Desa Pulo Blang Kecamatan Meurah Mulia Kabupaten Aceh Utara, pada bulan November 2016. Sedangkan untuk analisis laboratorium dilaksanakan di Laboratorium Fakultas Pertanian Universitas Malikussaleh. Analisis laboratorium dilaksanakan setelah selesai analisis secara visual di lapang.

Bahan yang digunakan adalah lahan yang hanya ditumbuhi oleh vegetasi alangalang, herbisida berbahan aktif glifosat (dengan merek dagang Round $U p$ ) dan pupuk urea. Alat-alat yang digunakan adalah petak contoh atau frame yang berukuran 50x50 cm, knapsack sprayer (semprot punggung) berkapasitas 14 liter, gelas ukur yang berukuran $1000 \mathrm{ml}$, tali rafia, oven, amplop ukuran HVS untuk membungkus gulma, timbangan analitik, parang, pisau, meteran, dan cangkul.

Penelitian ini menggunakan metode rancangan acak kelompok (RAK) pola faktorial. Ada dua faktor yang diteliti yaitu dosis glifosat $(\mathrm{G})$ dan pupuk urea $(\mathrm{P})$.

a. Faktor Dosis Glifosat (G), dengan taraf :

$\mathrm{G}_{0}=$ Kontrol

$\mathrm{G}_{1}=$ Glifosat dengan dosis $100 \mathrm{ml}$ liter

$\mathrm{G}_{2}=$ Glifosat dengan dosis $200 \mathrm{ml}$ liter

b. Faktor Pupuk Urea (P), dengan taraf :

$\mathrm{P}_{0}=$ Kontrol

$\mathrm{P}_{1}=$ Urea dengan dosis 400 gram

$\mathrm{P}_{2}=$ Urea dengan dosis 600 gram

Dengan demikian penelitian ini terdiri dari 9 kombinasi percobaan masingmasing dengan tiga ulangan, sehingga secara keseluruhan terdapat 27 unit percobaan. Adapun susunan kombinasi perlakuan dapat dilihat pada Tabel 1 .

Tabel 1. Susunan Kombinasi Campuran Herbisida Glifosat dan Pupuk Urea pada Beberapa Taraf Dosis untuk Mengendalikan Gulma Alang-alang

\begin{tabular}{cccc}
\hline & \multicolumn{3}{c}{ Dosis Pupuk Urea (P) } \\
\cline { 2 - 4 } Dosis Glifosat $(\mathrm{G})$ & $\mathrm{P}_{0}$ & $\mathrm{P}_{1}$ & $\mathrm{P}_{2}$ \\
\hline $\mathrm{G}_{0}$ & $\mathrm{G}_{0} \mathrm{P}_{0}$ & $\mathrm{G}_{0} \mathrm{P}_{1}$ & $\mathrm{G}_{0} \mathrm{P}_{2}$ \\
$\mathrm{G}_{1}$ & $\mathrm{G}_{1} \mathrm{P}_{0}$ & $\mathrm{G}_{1} \mathrm{P}_{1}$ & $\mathrm{G}_{1} \mathrm{P}_{2}$ \\
$\mathrm{G}_{2}$ & $\mathrm{G}_{2} \mathrm{P}_{0}$ & $\mathrm{G}_{2} \mathrm{P}_{1}$ & $\mathrm{G}_{2} \mathrm{P}_{2}$ \\
\hline
\end{tabular}

Model matematika untuk rancangan acak kelompok (RAK) faktorial adalah sebagai berikut:

$$
Y_{i j k}=\mu+\beta_{i}+G_{j}+P_{k}+(G P)_{j k}+\varepsilon_{i j k}
$$

Keterangan:

$\mathrm{Y}_{\mathrm{ijk}} \quad=$ Hasil pengamatan dari faktor dosis glifosat taraf ke i dan faktor pupuk urea ke-j pada ulangan ke-k

$\mu \quad=$ Rata-rata (nilai tengah)

$\beta_{\mathrm{i}} \quad=$ Pengaruh blok ke- $\mathrm{i}$

$\mathrm{G}_{\mathrm{j}} \quad=$ Pengaruh dosis glifosat ke- $\mathrm{j}$ 
$\mathrm{P}_{\mathrm{k}} \quad=\quad$ Pengaruh pupuk urea ke-k

$(\mathrm{GP})_{\mathrm{jk}}=$ Pengaruh interaksi pada faktor $\mathrm{G}$ ke-j dan faktor P ke-k

$\varepsilon_{\mathrm{ijk}}=$ Pengaruh acak yang menyebar normal

Data hasil pengamatan dianalisis secara statistik dengan menggunakan analisis ragam untuk rancangan acak kelompok (RAK) dan apabila berpengaruh nyata dan sangat nyata maka dilakukan uji lanjutan masing-masing perlakuan dengan menggunakan uji BNT pada taraf 5\% (Gomez dan Gomez, 1995).

\subsection{Pelaksanaan Penelitian}

\subsubsection{Persiapan Lahan}

Persiapan lahan meliputi pembagian luasan lahan yang ditumbuhi gulma alang-alang untuk dilakukan penyemprotan, dimana luasan semprot dibagi kedalam 27 petak (plot percobaan) dengan ukuran 1 x 1,2 meter dengan pengulangan penyemprotan masing-masing unit perlakuan sebanyak 3 kali. Untuk membuat plot atau memisahkan antara blok yang satu dengan blok yang lain maka digunakan tali rafia dengan cara membentangkan tali rafia pada kayu yang telah ditancapkan ke tanah membentuk persegi empat sesuai dengan ukuran plot yang telah ditentukan.

\subsubsection{Aplikasi Herbisisa Glifosat dan Pupuk Urea}

Aplikasi herbisisa glifosat dan pupuk urea dilakukan sesuai dengan unit percobaan yang sudah dipersiapkan dimana untuk setiap unit percobaan dicampur sesuai dengan ketetapan dan ditambahkan air sesuai dengan takaran yang telah ditetapkan. Selanjutnya herbisida glifosat yang telah dicampur dengan pupuk urea dimasukkan ke dalam knapsack sprayer (semprot punggung) berkapasitas 14 liter, namun air yang ditambahkan setelah dicampurkan antara herbisida dan pupuk urea hanya sampai tanda batas 2 liter air. Khusus untuk kontrol, hanya diberikan tanda batas saja dengan tali rafia tetapi tidak dilakukan perlakuan apa pun.

\subsection{Pengamatan}

Gulma yang dijadikan sebagai objek dalam penelitian ini adalah gulma yang tumbuh dilahan yang belum pernah digarap sama sekali yaitu milik petani di Desa Pulo Blang Kecamatan Meurah Mulia Kabupaten Aceh
Utara. Pengamatan di lapang dilakukan secara visual terhadap gulma alang-alang yang mencapai kerusakan hingga $95 \%$.

Pemanenan gulma dilakukan pada waktu 10 hari setelah aplikasi (HSA). Gulma dipisahkan antara bagian yang kering dan bagian yang masih segar dengan cara dipotong menggunakan pisau tajam. Masing-masing perlakuan ditimbang terlebih dahulu, kemudian dimasukkan ke dalam amplop dan diberi label sesuai perlakuan, selanjutnya dimasukkan ke dalam oven pada suhu $80^{\circ} \mathrm{C}$ selama dua hari, setelah itu gulma dikeluarkan dari oven dan dilakukan penimbangan kembali untuk memperoleh data bobot kering gulma. Adapun yang menjadi parameter pengamatan dalam penelitian ini yaitu:

a. Nilai Jumlah Dominansi (\%)

Nilai NJD merupakan jumlah angka kuantitatif spesies tertentu dari semua jenis unit sampel yang diambil. Nilai NJD dihitung dengan rumus :

Dominansi Mutlak

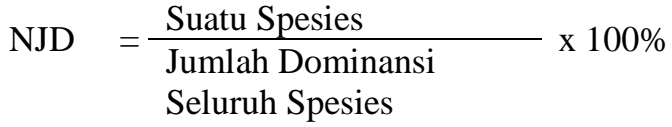

b. Persentase Kerusakan (\%)

Data bobot kering yang diperoleh selanjutnya dikonversi menjadi nilai persentase kerusakan yang ditimbulkan oleh campuran herbisida dengan pupuk urea pada beberapa dosis. Persentase kerusakan dihitung dengan menggunakan rumus sebagai berikut :

$\%$ Kerusakan $=\% \mathrm{KP}-\% \mathrm{KK}$

Keterangan :

$\% \mathrm{KP}=$ Persen kerusakan perlakuan

$\% \mathrm{KK}=$ Persen kerusakan control

c. Persentase Kerusakan Perlakuan (\%)

Persentase kerusakan perlakuan merupakan perbandingan antara bobot kering bagian gulma segar yang diperlakuan dengan bobot kering bagian gulma yang segar pada kontrol. Persentase kerusakan perlakuan dihitung dengan rumus:

$\% \mathrm{KP}=\left(1-\mathrm{B}_{\mathrm{sp}}\right) \times 100 \% \mathrm{~B}_{\mathrm{sk}}$

Keterangan :

$\% \mathrm{KP} \quad=$ Persen kerusakan perlakuan

$\% \mathrm{KK}=$ Persen kerusakan kontrol

$\mathrm{B}_{\mathrm{sp}}=$ Bobot kering bagian gulma segar yang diperlakuan (gram) 
$\mathrm{B}_{\mathrm{sk}}=$ Bobot kering bagian gulma segar yang kontrol (gram)

d. Persentase Kerusakan Kontrol (\%)

Persentase kerusakan kontrol merupakan perbandingan antara bobot kering bagian gulma yang mati pada kontrol dengan bobot kering total gulma pada control. Persentase kerusakan kontrol dihitung dengan rumus:

$$
\% \mathrm{KK}=\left(1-\mathrm{B}_{\mathrm{mk}}\right) \times 100 \% \mathrm{~B}_{\mathrm{tk}}
$$

Keterangan :

$\% \mathrm{KK}=$ Persen kerusakan kontrol

$\mathrm{B}_{\mathrm{mk}}=$ Bobot kering bagian gulma yang mati pada kontrol (gram)

$\mathrm{B}_{\mathrm{tk}} \quad=$ Bobot kering total gulma pada kontrol (gram)

\section{Hasil dan Pembahasan}

\section{Nilai Jumlah Dominasi (\%)}

Hasil analisis komposisi gulma didapatkan bahwa jenis gulma yang terdapat pada lokasi penelitian di Desa Pulo Blang Kecamatan Meurah Mulia Kabupaten Aceh Utara yaitu ada 3 jenis gulma yaitu jenis gulma berdaun lebar, berdaun sempit dan teki. Adapun spesies gulma yang terdapat pada lokasi penelitian di Desa Pulo Blang Kecamatan Meurah Mulia Kabupaten Aceh Utara disajikan pada Tabel 1.

Tabel 1. Spesies Gulma pada Lokasi Penelitian di Desa Pulo Blang Kecamatan Meurah Mulia Kabupaten Aceh Utara

\begin{tabular}{|c|c|}
\hline Jenis Gulma & NJD $(\%)$ \\
\hline Alang alang (Imperata cylindrica) & 30,36 \\
\hline Balakaciut (Galinsoga parviflora Cav.) & 18,75 \\
\hline Bribil (Galinsoga quadriradiata) & 16,07 \\
\hline Bayam Kremah (Altenanthera sessilis L.) & 14,29 \\
\hline Sembung Rambat (Mikania micrantha Kunth) & 12,50 \\
\hline Teki (Cyperus kyllingia Endl) & 8,04 \\
\hline Jumlah & 100 \\
\hline $\begin{array}{l}\text { Berdasarkan Tabel } 2 \text { menunjukkan } \\
\text { bahwa gulma berdaun lebar sebanyak } 3 \text { jenis } \\
\text { yaitu bribil (Galinsoga quadriradiata), } \\
\text { balakaciut (Galinsoga parviflora Cav.), dan } \\
\text { sembung rambat (Mikania micrantha Kunth). } \\
\text { Jenis gulma berdaun berdaun sempit sebanyak } 2 \\
\text { jenis yaitu bayam kremah (Altenanthera sessilis } \\
\text { L.), dan alang alang (Imperata cylindrica). } \\
\text { Sedangkan jenis gulma teki sebanyak } 1 \text { jenis } \\
\text { yaitu teki (Cyperus kyllingia Endl). }\end{array}$ & $\begin{array}{l}\text { Berdasarkan hasil penelitian dapat } \\
\text { dijelaskan bahwa dalam areal pertumbuhan } \\
\text { gulma alang-alang di Desa Pulo Blang } \\
\text { Kecamatan Meurah Mulia Kabupaten Aceh } \\
\text { Utara menunjukkan bahwa gulma alang alang } \\
\text { mendominasi dibandingkan dengan gulma } \\
\text { lainnya. Hal menandakan bahwa gulma alang- } \\
\text { alang mampu bersaing dengan gulma lainnya } \\
\text { dalam kondisi apa pun. }\end{array}$ \\
\hline $\begin{array}{l}\text { Jenis gulma yang mendominasi pada } \\
\text { hasil penelitian dengan menggunakan petak } \\
\text { contoh atau frame adalah jenis gulma berdaun } \\
\text { sempit yaitu gulma alang alang (Imperata } \\
\text { cylindrica) sebanyak } 34 \text { dengan nilai jumlah } \\
\text { dominasi (NJD) yaitu } 30,36 \% \text {. Sedangkan } \\
\text { jumlah gulma yang paling sedikit adalah jenis } \\
\text { gulma teki yaitu gulma teki (Cyperus kyllingia } \\
\text { Endl sebanyak 1 dengan nilai NJD yaitu } 8.04 \% \text {. }\end{array}$ & $\begin{array}{l}\text { Persentase Kerusakan (\%) } \\
\text { Hasil uji F pada analisis ragam } \\
\text { menunjukkan bahwa adanya interaksi yang } \\
\text { sangat nyata antara campuran herbisida glifosat } \\
\text { dengan pupuk urea pada beberapa taraf dosis } \\
\text { untuk mengendalikan gulma alang-alang (Tabel } \\
\text { 1). Rata-rata interaksi antara campuran herbisida } \\
\text { glifosat dengan pupuk urea pada beberapa taraf } \\
\text { dosis untuk mengendalikan gulma alang-alang } \\
\text { disajikan pada Tabel } 2 \text {. }\end{array}$ \\
\hline
\end{tabular}


Tabel 2. Interaksi antara Campuran Herbisida Glifosat dan Pupuk Urea terhadap Persentase Kerusakan Gulma Alang-alang

\begin{tabular}{cccc}
\hline \multirow{2}{*}{ Dosis Glifosat $(\mathrm{G})$} & \multicolumn{3}{c}{ Dosis Pupuk Urea $(\mathrm{P})$} \\
\cline { 2 - 4 } & $\mathrm{P}_{0}$ & $\mathrm{P}_{1}$ & $\mathrm{P}_{2}$ \\
\hline \multirow{2}{*}{$\mathrm{G}_{0}$} & $13,33 \mathrm{~b}$ & $31,67 \mathrm{a}$ & $33,33 \mathrm{a}$ \\
& $\mathrm{B}$ & $\mathrm{B}$ & $\mathrm{B}$ \\
$\mathrm{G}_{1}$ & $66,67 \mathrm{~b}$ & $65,00 \mathrm{~b}$ & $71,67 \mathrm{a}$ \\
& $\mathrm{B}$ & $\mathrm{B}$ & $\mathrm{B}$ \\
$\mathrm{G}_{2}$ & $83,33 \mathrm{~b}$ & $75,00 \mathrm{~b}$ & $88,33 \mathrm{a}$ \\
& $\mathrm{A}$ & $\mathrm{A}$ & $\mathrm{A}$ \\
\hline
\end{tabular}

Keterangan: Angka-angka yang diikuti oleh huruf kecil yang sama pada baris yang sama dan angka-angka yang diikuti oleh huruf besar yang sama pada kolom yang sama tidak berbeda nyata menurut BNT taraf 0.05 .

Tabel 3 menunjukkan bahwa adanya interaksi yang sangat nyata antara campuran herbisida glifosat dengan pupuk urea pada beberapa taraf dosis untuk mengendalikan gulma alang-alang. Hal ini menunjukkan bahwa perpaduan antara pemberian herbisida glifosat dengan dosis $200 \mathrm{ml}$ liter dan pupuk urea dengan dosis 600 gram mampu mengendalikan gulma alang-alang dibandingkan dengan perlakuan lainnya.

Hal ini terbukti dengan nilai persentase kerusakan gulma alang-alang sampai dengan $88,33 \%\left(\mathrm{G}_{2} \mathrm{P}_{2}\right)$. Sedangkan persentase kerusakan gulma terendah dijumpai pada kontrol yaitu dengan tingkat kerusakan hanya $13,33 \%\left(\mathrm{G}_{0} \mathrm{P}_{0}\right)$. Hasil penelitian membuktikan bahwa penggunaan herbisida berbahan aktif glifosat yang dicampur dengan Surfactant (pupuk urea) mampu mengendalikan gulma alang-alang. Sejalan dengan pendapat yang dikemukakan oleh Lamid et al., (2008) bahwa herbisida yang banyak digunakan saat ini sekitar $70 \%$ adalah herbisida berbahan aktif glifosat. Herbisida ini merupakan herbisida pasca tumbuh, sistemik, non selektif yang diaplikasikan melalui daun, mempunyai spektrum luas, bersifat translokatif kuat, tidak aktif dalam tanah, cepat terdegradasi dan mempunyai kemampuan mengendalikan gulma tahunan. Gejala kematian gulma terlihat pada 1 minggu setelah aplikasi.

\section{Persentase Kerusakan Perlakuan (\%)}

Hasil uji $F$ pada analisis ragam menunjukkan bahwa adanya interaksi yang sangat nyata antara campuran herbisida glifosat dengan pupuk urea pada beberapa taraf dosis untuk mengendalikan gulma alang-alang yang diukur dengan persentase kerusakan perlakuan (Lampiran 4). Rata-rata interaksi antara campuran herbisida glifosat dengan pupuk urea pada beberapa taraf dosis untuk mengendalikan gulma alang-alang disajikan pada Tabel 3 .

Tabel 3. Interaksi antara Campuran Herbisida Glifosat dan Pupuk Urea terhadap Persentase Kerusakan Perlakuan pada Gulma Alang-alang

\begin{tabular}{cccc}
\hline \multirow{2}{*}{ Dosis Glifosat $(\mathrm{G})$} & \multicolumn{3}{c}{ Dosis Pupuk Urea $(\mathrm{P})$} \\
\cline { 2 - 4 } & $\mathrm{P}_{0}$ & $\mathrm{P}_{1}$ & $\mathrm{P}_{2}$ \\
\hline \multirow{2}{*}{$\mathrm{G}_{0}$} & $18,75 \mathrm{a}$ & $18,95 \mathrm{a}$ & $21,82 \mathrm{a}$ \\
& $\mathrm{C}$ & $\mathrm{C}$ & $\mathrm{C}$ \\
$\mathrm{G}_{1}$ & $25,82 \mathrm{a}$ & $26,29 \mathrm{a}$ & $25,44 \mathrm{a}$ \\
& $\mathrm{B}$ & $\mathrm{B}$ & $\mathrm{B}$ \\
$\mathrm{G}_{2}$ & $32,59 \mathrm{c}$ & $46,04 \mathrm{~b}$ & $55,59 \mathrm{a}$ \\
& $\mathrm{A}$ & $\mathrm{A}$ & $\mathrm{A}$ \\
\hline
\end{tabular}

Keterangan: Angka-angka yang diikuti oleh huruf kecil yang sama pada baris yang sama dan angka-angka yang diikuti oleh huruf besar yang sama pada kolom yang sama tidak berbeda nyata menurut BNT taraf 0.05 . 
Tabel 3 menunjukkan bahwa adanya interaksi yang sangat nyata antara campuran herbisida glifosat dengan pupuk urea pada beberapa taraf dosis untuk mengendalikan gulma alang-alang yang diukur dengan persentase kerusakan perlakuan. Hal ini menunjukkan bahwa perpaduan antara pemberian herbisida glifosat dengan dosis $200 \mathrm{ml}$ liter dan pupuk urea dengan dosis 600 gram mampu mengendalikan gulma alang-alang dibandingkan dengan perlakuan lainnya.

Hal ini terbukti dengan nilai persentase kerusakan perlakuan terhadap gulma alang-alang mencapai 55,59\% $\left(\mathrm{G}_{2} \mathrm{P}_{2}\right)$. Sedangkan persentase kerusakan perlakuan terhadap gulma terendah dijumpai pada kontrol yaitu dengan tingkat kerusakan perlakuan hanya $18,75 \%\left(\mathrm{G}_{0} \mathrm{P}_{0}\right)$. Hasil penelitian membuktikan bahwa penggunaan herbisida berbahan aktif glifosat yang dicampur dengan Surfactant (pupuk urea) mampu mengendalikan gulma alang-alang mencapai $55,59 \%$.

Pupuk urea yang diaplikasi dalam penelitian ini bukan bertindak sebagai pupuk penambah unsur hara namun bertindak sebagai surfactan, surfactan ini tidak saja mampu mengurangi ketegangan permukaan untuk memperluas kontak antara butiran semprot dengan permukaan daun, namun juga mampu mendorong kemampuan penetrasi herbisida ke dalam daun untuk menjadi lebih baik.

Menurut Sukman (2002) herbisida merupakan senyawa kimia yang digunakan untuk mengendalikan, mematikan, atau menghambat pertumbuhan gulma tanpa mengganggu tanaman pokok. Untuk dapat memakai herbisida dengan baik, kita perlu mengetahui herbisida tersebut dengan baik pula. Sehingga dilakukan pengolongan herbisida dengan tujuan untuk mempermudah pengenalan jenis herbisida yang banyak jenisnya. Dengan adanya penggolongan tersebut akan lebih mudah mendalami dan mengenal sifat masing-masing herbisida

\section{Persentase Kerusakan Kontrol (\%)}

Secara visual tidak menunjukkan adanya pengaruh terhadap persentase kerusakan kontrol karena pada pengamatan ini tidak dilakukan perlakuan apapun. Namun hasil uji F pada analisis ragam menunjukkan bahwa adanya interaksi yang nyata antara campuran herbisida glifosat dengan pupuk urea pada beberapa taraf dosis untuk mengendalikan gulma alang-alang yang diukur dengan persentase kerusakan kontrol (Lampiran 6). Rata-rata interaksi antara campuran herbisida glifosat dengan pupuk urea pada beberapa taraf dosis untuk mengendalikan gulma alang-alang disajikan pada Tabel 4.

Tabel 4. Interaksi antara Campuran Herbisida Glifosat dan Pupuk Urea terhadap Persentase Kerusakan Kontrol Gulma Alang-alang

\begin{tabular}{cccc}
\hline \multirow{2}{*}{ Dosis Glifosat $(\mathrm{G})$} & \multicolumn{3}{c}{ Dosis Pupuk Urea (P) } \\
\cline { 2 - 4 } & $\mathrm{P}_{0}$ & $\mathrm{P}_{1}$ & $\mathrm{P}_{2}$ \\
\hline \multirow{2}{*}{$\mathrm{G}_{0}$} & $24,29 \mathrm{a}$ & $24,52 \mathrm{a}$ & $24,12 \mathrm{a}$ \\
& $\mathrm{A}$ & $\mathrm{A}$ & $\mathrm{B}$ \\
$\mathrm{G}_{1}$ & $24,09 \mathrm{a}$ & $23,90 \mathrm{~b}$ & $24,24 \mathrm{a}$ \\
& $\mathrm{A}$ & $\mathrm{A}$ & $\mathrm{B}$ \\
$\mathrm{G}_{2}$ & $24,20 \mathrm{~b}$ & $24,29 \mathrm{~b}$ & $25,60 \mathrm{a}$ \\
& $\mathrm{A}$ & $\mathrm{A}$ & $\mathrm{A}$ \\
\hline
\end{tabular}

Keterangan: Angka-angka yang diikuti oleh huruf kecil yang sama pada baris yang sama dan angka-angka yang diikuti oleh huruf besar yang sama pada kolom yang sama tidak berbeda nyata menurut BNT taraf 0.05 .

Tabel 4 menunjukkan bahwa secara visual tidak menunjukkan adanya pengaruh terhadap persentase kerusakan kontrol karena pada pengamatan ini tidak dilakukan perlakuan apapun. Namun secara analisis yaitu dengan uji F maka pada perlakuan persentase kerusakan kontrol berpengaruh nyata. Hal ini menunjukkan bahwa gulma yang tidak disemprot dengan campuran herbisida glifosat dan pupuk urea pada beberapa taraf dosis tidak berpengaruh terhadap persentase kerusakan kontrol yang dibuktikan dengan nilai masing-masing perlakuan yang tidak jauh berbeda. 


\section{Simpulan}

Berdasarkan hasil penelitian yang telah dilakukan, maka dapat disimpulkan sebagai berikut:

1. Campuran herbisida glifosat dan pupuk urea pada beberapa taraf dosis dapat menekan pertumbuhan dan perkembangan gulma alang-alang.

2. Campuran herbisida glifosat dengan dosis $200 \mathrm{ml}$ liter dan pupuk urea dosis 600 gram $\left(\mathrm{G}_{2} \mathrm{P}_{2}\right)$ merupakan dosis terbaik untuk mengendalikan pertumbuhan dan perkembangan gulma alang-alang.

\section{Daftar Pustaka}

Adimihardja. 2005. Teknologi Pengelolaan Lahan Kering. Pusat Penelitian dan Pengembangan Tanah dan Agroklimat. Badan Penelitian dan Pengembangan Pertanian Departemen Pertanian, Bogor.

Anonymous. 2007. Kedelai Teknik Produksi dan Pengembangannya. Pusat Penelitian dan Pengembangan tanaman Pangan, Badan Penelitian dan Pengembangan Pertanian.

Damaru. 2011. Alang-alang. Makalah Ekologi Tumbuhan. Universitas Sumatera Utara. Medan.

Daud, David. 2008. Uji Efikasi Herbisida Glifosat, Sulfosat dan Paraquat pada Sistim Tanpa Olah Tanah (TOT) Jagung. Prosiding Seminar Ilmiah dan Pertemuan Tahunan PEI PFI XIX Komisariat Daerah Sulawesi Selatan.

Djafaruddin. 2004. Dasar-dasar Perlindungan Tanaman. Bumi Aksara. Jakarta.

Djojosumarto, Panut. 2008. Pestisida dan Aplikasinya. Agromedia Pustaka. Jakarta.

Gomez, K. A. dan Gomez, A., A. 1995. Prosedur Statistik untuk Penelitian Pertanian. Edisi Kedua. UI Press. Jakarta. 698 hal.

James, T.K. and A. Rahman. 2005. Efficacy of several organic herbicides and glyphosate formulations under simulated rainfall. JournalNew Zealand Plant Protection 58:157-163.

Lamid, Z.G., Adilis, H., dan Hermawan, G. 2008. Efikasi Herbisida Glifosat terhadap Gulma dalam Pengolahan Pengembangan Gulma Secara Efisien Berwawasan Lingkungan Menuju Pertanian Berkelanjutan. Prosiding 14 HIGI. Edisi 402-409. Medan.

Lingga, $P$ dan Marsono.2002.Petunjuk Penggunaan Pupuk. Penebar Swadaya: Jakarta.

Lingga, P. 2003. Petunjuk Penggunaan Pupuk. Penebar Swadaya. Jakarta.

Martin, J. 2006. Dasar-dasar Mata Kuliah Gulma di Jurusan Biologi. Universitas Udayana. Bali.

Nanik, S. 2010. Pengelolaan Gulma dan Herbisida untuk Meningkatkan Produktivitas Lahan Pertanian secara Berkelanjutan. Universitas Bandar Lampung.. Lampung.

Pranata, A.,S. 2004. Pupuk Organik Cair, Aplikasi dan Manfaatnya. Edisi Pertama. Agromedia Pustaka. Jakarta.

2005.Pupuk Organik Cair, Aplikasi dan Manfaatnya. Edisi Kedua. Agromedia Pustaka. Jakarta.

Purba, Edison. 2009. Keanekaragaman Herbisida dalam Pengendalian Gulma Mengatasi Populasi Gulma Resisten dan Toleran Herbisida. Medan : Universitas Sumatera Utara (Pidato Pengukuhan Jabatan Guru Besar Tetap dalam Bidang Ilmu Gulma pada Fakultas Pertanian).

Sastroutomo. 2000. Ekologi Gulma. Gramedia Pustaka Utama. Jakarta.

Sembodo, 2010. Gulma dan Pengelolaannya. Graha Ilmu. Yogyakarta.

Soerjandono, N., B. 2005. Teknik Pengendalian Gulma dengan Herbisida Persistensi 
Jurnal Agrium 14(1),Maret 2017. Hlm. 17-25

ISSN 1829-9288

Rendah Pada Tanaman Padi. Buletin

Teknik Pertanian Vol. 10, Nomor 1

Soekisman. 2004. Pengolahan Gulma. Gramedia Pustaka. Jakarta.

Sudarmo, S. 2007. Pestisida. Kanisius. Yogyakarta.

Sukman, Y. 2002. Gulma dan Teknik Pengendaliannya. Rajawali Press, Jakarta. 